\title{
Role of Acacia seyal on Selected Soil Properties and Sorghum Growth and Yield: A Case Study of Guba Lafto District, North Wollo, Ethiopia
}

\author{
Alayu Haile Belayneh ${ }^{D},{ }^{1}$ Kidane Giday Gebremedhin, ${ }^{2}$ and Yemane G. Egziabher ${ }^{3}$ \\ ${ }^{1}$ Ethiopian Environment and Forest Research Centre, P.O. Box 2128, Bahir Dar, Ethiopia \\ ${ }^{2}$ Department of Land Resources Management and Environmental Protection, Mekelle University, Mekelle, Ethiopia \\ ${ }^{3}$ Department of Dry Land Crop and Horticultural Sciences, Mekelle University, Mekelle, Ethiopia
}

Correspondence should be addressed to Alayu Haile Belayneh; aluh19@gmail.com

Received 3 October 2020; Revised 14 December 2020; Accepted 19 December 2020; Published 7 January 2021

Academic Editor: Vera Popovic

Copyright (c) 2021 Alayu Haile Belayneh et al. This is an open access article distributed under the Creative Commons Attribution License, which permits unrestricted use, distribution, and reproduction in any medium, provided the original work is properly cited.

\begin{abstract}
Acacia seyal is one of the multipurpose parkland agroforestry tree species in eastern and southern Africa. It is a common on-farm tree in the Rift Valley of Ethiopia, but information is limited on its effect on soil properties and sorghum growth and yield. The study was conducted to evaluate its effect on selected soil properties and sorghum growth and yield in Guba Lafto district of northern Ethiopia. Six isolated and closely comparable Acacia seyal trees growing on sorghum farms were purposely selected, and plots were marked under the canopy of trees with three radial distances $(0-2 \mathrm{~m}, 2-4 \mathrm{~m}$, and $4-6 \mathrm{~m})$ and one outside of the tree canopy ( $10 \mathrm{~m}$ away from any tree). Soil samples from each distance zone were taken between $0-20 \mathrm{~cm}$ and $20-40 \mathrm{~cm}$ soil depths for soil property analysis. Four quadrates with $1 \mathrm{~m}^{2}$ at each distance zone in four directions were laid for sorghum growth and yield attribute valuation. The results showed that only total nitrogen $(\mathrm{TN})$ was significantly higher $(P<0.05)$ at the subsoil layer under the canopy compared to an open area, while other selected soil parameters were not affected by the tree species. Sorghum biomass yield $(P=0.006)$ and grain yield $(P=0.025)$ were significantly lower under the canopy of the trees than in the open area. Generally, Acacia seyal had little effect in improving soil properties and showed a negative effect on sorghum yield and growth. Further research on its effect under wide area coverage of parkland system should be performed to bring a radical shift on the intercropping farming system.
\end{abstract}

\section{Introduction}

The human population growth rate in sub-Saharan Africa is increasing rapidly despite the lower rate of food production which needs alternative solutions for parallel growth [1]. On the other hand, climate change is a major constraint for declining agricultural productivity which created a food crisis particularly for smallholder farmers. This needs climate mitigation action and climate-resilient agricultural strategy [2]. High chemical fertilizer input and fast-tracked soil fertility loss are also becoming another challenging factor for sustainable agricultural land productivity and wide environmental problems $[1,3,4]$. Inorganic or artificial fertilizer applications are also risky for the environment and found inhibiting the naturally important nodulation and nitrogen fixation and symbiotic associations which again affect nutrient recycling $[5,6]$.

Thus, agricultural productivity reduction and food crisis challenges call for creating a multifunctional agricultural system that fulfills both intensified crop productivity improvement and socioeconomically valuable farming systems $[7,8]$. Improving the current farming system such as climate-smart agriculture and sustainable productivity is important for sustainable development and food security via 
increasing agricultural productivity and enhancing the resilience of livelihoods and ecosystems to climate change $[9,10]$.

Among the different existing options, agroforestry is one of the environmentally friendly approaches that help farmland soil improve and checked for smallholder farmers $[9,11]$. It has many provisional, regulating, and cultural services, considered as climate-resilient and adaptation mechanisms [12-15]. Maintenance and improving existing practices and incorporation of multipurpose trees (MPTs) on farms are recognized as critical interventions to increase agricultural productivity in a sustainable way $[9,11]$. Trees are advantageous for protecting environmental degradation, reducing external input costs, generally considered as a means for organic farming which assures agricultural sustainability [16]. Moreover, nitrogen-fixing legume trees get attention for nitrogen fertilizer enhancement, thereby enhancing crop productivity and creating an opportunity for sustainability $[4,6,17]$.

Acacia seyal is one of the drought-tolerant agroforestry tree species found in eastern and southern Africa and native trees to the Sahelian zone of Africa $[18,19]$. It has a typical drought avoidance strategy and is adaptable to water stress conditions [20]. Unlike most other legume tree species, it nodules with both fast-growing (Rhizobium) and slowgrowing (Bradyrhizobium) bacteria strains which strengthen its role in nitrogen fixation and soil improvement ability [21]. Limited research investigations were carried out so far on Acacia seyal effect and its social contribution in various countries at different levels [22-24]. In the study area, different thickets of Acacia spp. are growing in undulating hills and farmlands. The farming communities allow Acacia seyal to grow in their farmlands. The species seems well synchronized with the farming communities. However, its contribution to soil fertility and sorghum productivity has been the least studied. Therefore, this study was designed to investigate the effect of Acacia seyal on selected soil properties and sorghum growth and yield attributes in farmlands during the main rainy season in Guba Lafto district, North Wollo Zone.

\section{Materials and Methods}

2.1. Study Area Description. The study area is located in Guba Lafto district, North Wollo Zone of Amhara National Regional State, Ethiopia (Figures 1 and 2), which is between $39^{\circ} 6^{\prime} 9^{\prime \prime}$ to $39^{\circ} 45^{\prime} 58^{\prime \prime}$ East and $11^{\circ} 34^{\prime} 54^{\prime \prime}$ to $11^{\circ} 58^{\prime} 59^{\prime \prime}$ North, and altitude ranges are between 1379 and 3200 m.a.s.l. It is situated $521 \mathrm{~km}$ North from Addis Ababa. The soil texture of the area is dominated by sandy clay $(46 \%)$, clay-loam-brown (39\%), and small percentages of sandy soil (8\%) and silt soil (7\%) [25]. Lithic Leptosols (92.2\%) is dominated by soil type in the district followed by Eutric Cambisols (3.9\%) and Eutric Leptosols (3.5\%) [26]. The district is majorly described with mid (Woina Dega) agroecological conditions (46\%). Rainfall is poor in distribution in the area, and it receives a bimodal rainy season in summer and short winter seasons. The mean annual and monthly rainfall and temperature range from 800 to $1050 \mathrm{~mm}$ and $21^{\circ} \mathrm{C}$ to $25^{\circ} \mathrm{C}$, respectively [25]. Subsistence agriculture is the main livelihood system of the rural population with commonly mixed crop and livestock farming systems. Agricultural land is limited, which is $36 \%$ of the total land, and landholding size per household ranges from 0.4 to 1.93 ha [27]. Among various cereals and pulses, sorghum (Sorghum bicolor) and teff (Eragrostis tef) were commonly cultivated crops, especially during the summer rainy season.

2.2. Experimental Design and Treatment. Sorghum (var Jamyo) farmlands with similar crop history and management were systematically selected from farm communities at household level. Then, six Acacia seyal (var Fistula) trees were selected randomly from systematically selected trees along with sorghum farms. Tree height, diameter at breast height $(\mathrm{DBH})$, and canopy diameter were measured (Table 1). The diameter at breast height was measured over the bark in $\mathrm{cm}$ via a caliper, the canopy radius was obtained by the measurement of crown width using a meter tape in both directions and the average value $(\mathrm{m})$ is taken, and the height measurement was taken via a Suunto clinometer (m). Soil sampling and sorghum growth and yield measurements were obtained under three concentric radial distances (subplots) of the selected Acacia seyal and one from the open area near the base $(0-2 \mathrm{~m})$, under the canopy $(2-4 \mathrm{~m})$, the edge of the canopy (4-6 m), and control plot with $10 \mathrm{~m}$ away from the tree base in four directions.

2.3. Soil Sampling and Analysis. The soil sample was taken from each of the four radial distances of the tree, namely, D1, D2, D3, and D4, from the open area (Figure 3), via a stainless auger [28] in four directions with two soil depths of $0-20 \mathrm{~cm}$ and $20-40 \mathrm{~cm}[29,30]$ at the end of the long rainy cropping season. A total of 48 composite soil samples taken from 6 plots, 2 depths, and 4 concentric distance zones were sampled and analyzed at Sirinka Regional Research Center Soil Lab. Soil $\mathrm{pH}$ was determined by using a $\mathrm{pH}$ meter in a 1 : 2.5 soil; water suspension and soil electrical conductivity (EC) were measured using a conductivity meter in saturated paste extract. Total nitrogen (TN) was determined by the Kjeldahl acid digestion method [31], available phosphorus was determined via absorbance on a spectrophotometer following Olsen [32], cation-exchange capacity (CEC) was determined after extraction of soil with the ammonium acetate method at $\mathrm{pH} 7$ following Chapman [33], soil organic carbon was determined via the oxidation method [34], soil bulk density (BD) was estimated via the oven-dry method [35], moisture content (MC) was determined by the gravimetric method [36], and texture was determined by Bouyoucos methods using a hydrometer [37].

Growth and yield parameters of sorghum were collected from each subplot of square meter. Sorghum plant stock height and panicle length were recorded using a meter tape from 10 randomly selected sorghum plants of the net quadrant at harvest time. Total numbers of sorghum plants counted in each subplot were taken and used as their average value. Aboveground biomass of sampled sorghum was sundried to constant weight, and biomass yield $\left(\mathrm{kg} / \mathrm{m}^{2}\right)$ was 


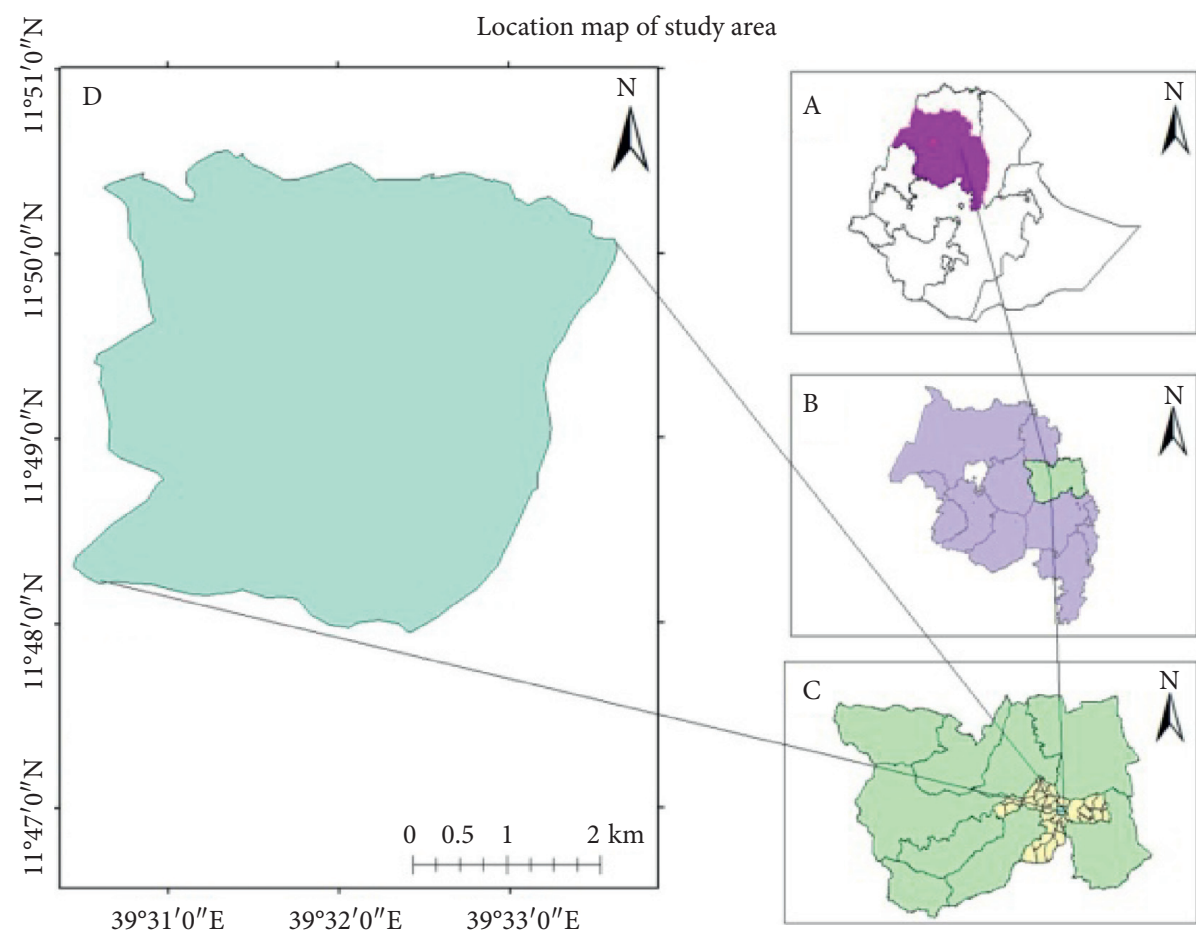

D Jarsa_kebele

C North wollo_Z

B Amhara_reg

A Ethio-regious

FIgURE 1: Geographical map showing the location of the study site.

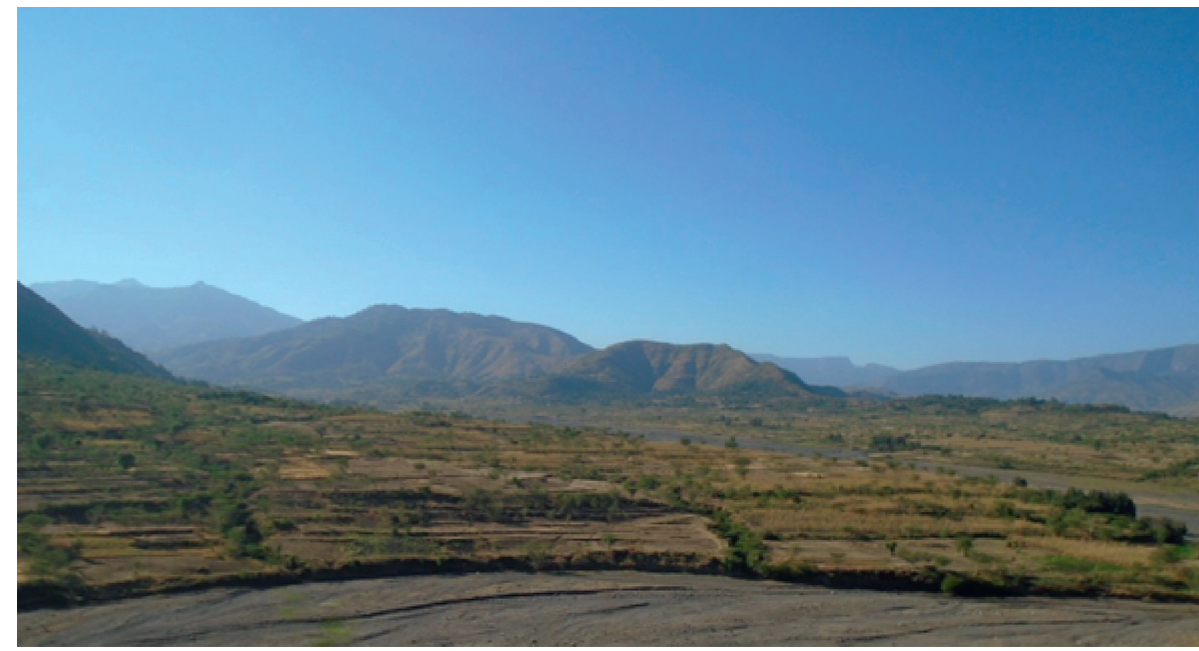

FIgURE 2: Jarsa kebele research site.

estimated on $\mathrm{kg} / \mathrm{ha}$ basis. The standing sorghum plant panicles were collected and manually threshed; the grains were cleaned and weighted at $12.5 \%$ moisture level, and the yield was estimated per hectare basis. 1000 kernel weights in gram (gm) were manually counted and weighted. The sorghum yield $(\mathrm{kg} / \mathrm{ha})$ was estimated as a total sum of biomass and grain yield. Harvest index of sorghum was determined as a fraction of grain yield in the unit of measurement of total yield and expressed in percentage (harvest index $(\%)=$ grain yield/biological yield $($ grain + straw $) \times 100)[38]$.

2.4. Statistical Analysis. Assumptions of normality and homogeneity of variance were first checked via the Shapiro-Wilk test and Levene test, respectively [39], for 
TABLE 1: DBH, canopy size, and height of selected Acacia seyal trees for the study.

\begin{tabular}{|c|c|c|c|c|c|c|}
\hline \multirow{2}{*}{ Plot no. } & \multirow{2}{*}{$\mathrm{DBH}(\mathrm{cm})$} & \multirow{2}{*}{ Canopy size (m) } & \multirow{2}{*}{ Total height $(\mathrm{m})$} & \multicolumn{3}{|c|}{ Coordination } \\
\hline & & & & $X$ & Y & $Z$ \\
\hline 1 & 57 & 6.43 & 9.65 & 559404 & 1307856 & 1797 \\
\hline 2 & 49 & 4.60 & 7.32 & 559747 & 1308196 & 1796 \\
\hline 3 & 48 & 4.55 & 7.50 & 559275 & 1308479 & 1818 \\
\hline 4 & 62 & 6.20 & 9.40 & 558211 & 1307977 & 1836 \\
\hline 5 & 56 & 7.00 & 8.00 & 558201 & 1308120 & 1833 \\
\hline 6 & 49 & 5.70 & 7.80 & 557985 & 1308140 & 1866 \\
\hline Min & 48 & 4.55 & 7.32 & & & \\
\hline Max & 62 & 7 & 9.65 & & & \\
\hline Mean & 53.50 & 5.75 & 8.28 & & & \\
\hline St. error \pm & 2.320 & 0.41 & 0.41 & & & \\
\hline
\end{tabular}

Plot geographical coordination was taken with GPS gadget (Garmin, USA).

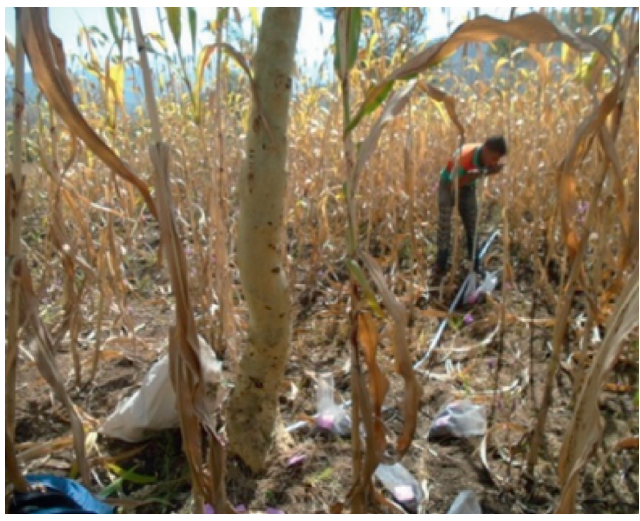

(a)

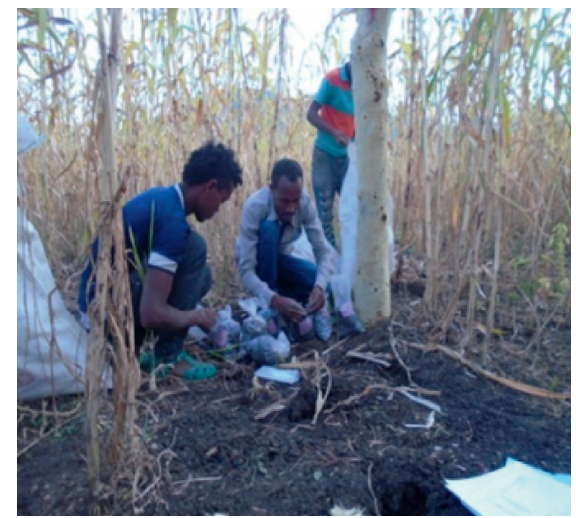

(b)

FIgURE 3: Soil sampling under tree canopy.

meaningful interpretation. The post hoc LSD test was used to determine the significant difference between treatments at $5 \%$ probability level. Characteristics of trees, soil physiochemical properties, and sorghum growth and yield parameters were described by using mean and standard deviation via descriptive statistics. The effects of tree on soil properties and sorghum growth and yield were tested by using the one-way analysis of variance and split file method. Two-way analysis of variance was employed to check the interaction between radial distance and soil depth treatments by using Wilks' lambda test [40]. Selected soil properties' mean value variation along soil depth was also tested by independent $t$-test along with each radial distance of tree. For data analysis, SPSS version 20 software (SPSS Corp., Chicago, USA) was used.

\section{Results and Discussion}

\subsection{Effect of Acacia seyal on Soil Properties}

3.1.1. Soil Physical Properties. Soil particle fractions did not significantly vary $(P>0.05)$ with distance from tree, showing that the soil properties were less affected by management practices [41-43]. Similar findings were reported for the case of different parkland tree species such as Acacia seyal, Ziziphus spina-christi, and Acacia senegal [44-46]. In contrary to this, a study in Saudi showed a significant variation of texture following distance from Acacia tree species, other than Acacia seyal species, where the clay percentage was higher under the canopy of the species than outside the canopy [47]. This difference probably was due to species variation [19] and land use type where those species were used as woodlots for a bit longer time which could bring changes to soil texture compared to the open area.

Moisture content was not significantly affected by the species along both soil depths $(P>0.05)$ at the harvesting season (Table 2). However, the lowest (34.64\%) and highest (35.72\%) moisture contents were recorded near the tree base (D1) and the edge of the canopy (D3), respectively, for the topsoil layer (Table 2). Normally, tree species are expected to maintain soil moisture by reducing rain speed and increasing infiltration rate [48]. However, such was not the case with Acacia seyal and this might be due to competition effect of small diameter and superficial lateral roots of the species [49]. Similar results for Balanites aegyptiaca, Acacia tortilis, and Ziziphus spina-christi species, respectively, on crop farms were found by Kassa et al. [50], Akpo et al. [51], and Wolle et al. [45]. Bulk density (BD) was statistically in par across the distance from tree and soil depths (Table 2). It might be due to low organic carbon availability under the canopy of a tree which directly influences soil aggregate stability which again affects the bulk density of soil. 
TABLE 2: Mean values $( \pm S D)$ of selected soil physical parameters under soils in different distances from trees and two soil depths in Acacia seyal parkland system.

\begin{tabular}{|c|c|c|c|c|c|c|}
\hline \multirow{2}{*}{ Soil properties } & \multirow{2}{*}{ Soil depth } & \multicolumn{4}{|c|}{ Distance from tree } & \multirow{2}{*}{$P$ value } \\
\hline & & Near tree bole & Under canopy & Edge of canopy & Far from canopy & \\
\hline \multirow{2}{*}{ Clay (\%) } & 1 & $55.25^{\mathrm{a}} \pm 1.73$ & $56.25^{\mathrm{a}} \pm 4.47$ & $56.17^{\mathrm{a}} \pm 3.25$ & $55.0^{\mathrm{a}} \pm 7.86$ & 0.958 \\
\hline & 2 & $56.67^{\mathrm{a}} \pm 5.79$ & $56.83^{a} \pm 6.13$ & $58.58^{\mathrm{a}} \pm 3.56$ & $55.42^{\mathrm{a}} \pm 9.44$ & 0.871 \\
\hline \multirow{2}{*}{ Silt (\%) } & 1 & $22.83^{\mathrm{a}} \pm 3.02$ & $23.58^{\mathrm{a}} \pm 1.36$ & $21.42^{\mathrm{a}} \pm 2.13$ & $23.75^{\mathrm{a}} \pm 3.45$ & 0.418 \\
\hline & 2 & $23.17^{\mathrm{a}} \pm 4.86$ & $24.75^{\mathrm{a}} \pm 2.21$ & $20.83^{\mathrm{a}} \pm 2.62$ & $23.75^{\mathrm{a}} \pm 3.45$ & 0.272 \\
\hline \multirow{2}{*}{ Sand (\%) } & 1 & $21.92^{\mathrm{a}} \pm 2.94$ & $20.83^{\mathrm{a}} \pm 3.47$ & $22.42^{\mathrm{a}} \pm 4.23$ & $21.25^{\mathrm{a}} \pm 5.9$ & 0.921 \\
\hline & 2 & $20.17^{\mathrm{a}} \pm 4.6$ & $18.42^{\mathrm{a}} \pm 5.65$ & $20.08^{\mathrm{a}} \pm 3.92$ & $20.83^{\mathrm{a}} \pm 7.3$ & 0.891 \\
\hline \multirow{2}{*}{ MC (\%) } & 1 & $34.64^{\mathrm{a}} \pm 1.16$ & $35.06^{\mathrm{a}} \pm 1.06$ & $35.72^{\mathrm{a}} \pm 2.02$ & $34.77^{\mathrm{a}} \pm 1.83$ & 0.649 \\
\hline & 2 & $35.09^{\mathrm{a}} \pm 1.44$ & $34.90^{\mathrm{a}} \pm 0.32$ & $35.18^{\mathrm{a}} \pm 1.04$ & $34.86^{\mathrm{a}} \pm 0.89$ & 0.937 \\
\hline \multirow{2}{*}{$\mathrm{BD}\left(\mathrm{gm} / \mathrm{cm}^{3}\right)$} & 1 & $1.06^{\mathrm{a}} \pm 0.04$ & $1.06^{\mathrm{a}} \pm 0.03$ & $1.03^{\mathrm{a}} \pm 0.08$ & $1.07^{\mathrm{a}} \pm 0.08$ & 0.63 \\
\hline & 2 & $1.05^{\mathrm{a}} \pm 0.06$ & $1.04^{\mathrm{a}} \pm 0.03$ & $1.05^{\mathrm{a}} \pm 0.04$ & $1.06^{\mathrm{a}} \pm 0.04$ & 0.94 \\
\hline
\end{tabular}

Rows with the same superscript letters are not significantly different at $P<0.05$; soil depth with 1 and 2 represents $0-20 \mathrm{~cm}$ and $20-40 \mathrm{~cm}$, respectively.

3.1.2. Soil Chemical Properties. Soil $\mathrm{pH}$ and electrical conductivity (EC) were found not significantly influenced by the presence of Acacia seyal under both soil layers (Table 3). However, electrical conductivity (EC) was a bit higher, ranging from 0.053 to $0.077 \mathrm{ds} / \mathrm{m}$ at the subsoil layer than surface soil which ranges from 0.048 to $0.063 \mathrm{ds} / \mathrm{m}$ (Table 3). This indicates that the surface soil looks less saline than subsurface soil [52]. Even though not significant, it was also relatively higher around the tree bole than an open area. This might be due to the microbial association and low leaching problems of base-forming cations around a tree [53]. The result agreed with Kassa et al. [50] and Wolle et al. [45] who reported nonsignificant effects of Balanites aegyptiaca and Ziziphus spina-christi over EC at the arid areas of Humera and Hibru districts of Ethiopia, respectively.

Besides that soil organic carbon (SOC) was expected to be significantly higher under the tree canopy, as most perennial trees contributed to organic matter input via litterfall and fine root turnover. In this study, this was not confirmed. This might be due to the lower contribution of litter decomposition to soil carbon [54]. It was in line with the finding for an integrated system of Acacia seyal with sorghum cropping system in Sudan [55].

TN was significantly affected by the presence of Acacia seyal tree species $(P=0.035)$ under the subsoil layer $(20-40 \mathrm{~cm})$ with $P \leq 0.05$ (Table 3$)$. Acacia seyal showed a positive significant effect $(P=0.035)$ of the available nitrogen of the subsurface soil (Table 3). Decreasing trend was observed from the tree base to the open area. The pattern was expected since most legume tree species, including Acacia seyal, have a positive effect on soil total $\mathrm{N}[56,57]$. It may also be associated with under-tree organic carbon availability via litterfall and fine root turnover from trees and droppings of animals resting under the tree [58]. Likewise, higher ( $42 \%$ more) nitrogen availability under the canopy of Acacia seyal compared to the open area was reported in the Rift Valley of Ethiopia [44]. The similar findings on different agroforestry tree species was also reported by Boffa et al. [59] and Hassan et al. [60]. Available phosphorus was found not affected by the species, and this might be due to the lower litter accumulation potential of the species which is related to organic phosphorus availability.
Numerically, CEC had a lower mean value around the root zone for both soil depths compared to the open area but was not statistically different (Table 3 ). In agreement with this, lower but statistically similar CEC values under Acacia seyal in the sorghum intercropping system was reported by Deng et al. [55]. Different parkland species such as Balanites aegyptiaca and Ziziphus spina-christi were reported as having similar effects but other species such as Acacia tortilis and Faidherbia albida showed a positive significant effect on CEC $[44,45,50]$. This might be due to the significant effect of those species on SOC which are directly related with CEC, and in the other ways, SOC was statistically similar in our case [58].

\subsection{Effect of Acacia seyal on Sorghum Growth and Yield.} The presence of Acacia seyal had a significant negative effect on aboveground biomass $(P=0.006)$ and grain $(P=0.025)$ yields of sorghum (Figure 4$)$. However, other growth and yield attributes were not statistically affected $(P>0.05)$. This might be due to the shading effect of the trees on seed emergence and seedling survival and could also be due to allopathic and superficial root competition effects of the species $[49,61]$. It could also be due to the shade intolerance character of sorghum [62] which highly affected its undercanopy performance [61].

Sorghum aboveground biomass (AGB) and grain yield were found affected by the presence of Acacia seyal $(P \leq 0.05)$. AGB was lower at D1 $(2368.33 \mathrm{~kg} / \mathrm{ha})$ compared to D4 $(6558.33 \mathrm{~kg} / \mathrm{ha})$ with more than fold amount $(177 \%)$ (Figure 4). It might be correlated with the number of sorghum stands counted and its growth performance [62]. Grain yield was also observed to be higher (142\% more) at D4 compared to D1 (Figure 4). The result was unexpected since the symbiotic and nitrogen-fixing ability of Acacia seyal is believed to boost yield by enhancing soil fertility [21]. However, this might be due to the shading effect of Acacia seyal and its allopathic effect on sorghum survival and growth performance which is directly related to yield $[49,61]$. Superficial small diameter roots at the surface layer and underground root competition of the species also 
TABLe 3: Mean values $( \pm S D)$ of selected soil chemical parameters under soils in different distances from trees and two soil depths in Acacia seyal parkland system.

\begin{tabular}{|c|c|c|c|c|c|c|}
\hline \multirow{2}{*}{ Soil properties } & \multirow{2}{*}{ Soil depth } & \multicolumn{4}{|c|}{ Distance from tree } & \multirow{2}{*}{$P$ value } \\
\hline & & Near tree bole & Under canopy & Edge of canopy & Far from canopy & \\
\hline \multirow{2}{*}{$\mathrm{pH}$} & 1 & $6.3^{\mathrm{a}} \pm 0.21$ & $6.27^{\mathrm{a}} \pm 0.16$ & $6.25^{\mathrm{a}} \pm 0.19$ & $6.25^{\mathrm{a}} \pm 0.29$ & 0.99 \\
\hline & 2 & $6.25^{\mathrm{a}} \pm 0.19$ & $6.25^{\mathrm{a}} \pm 0.21$ & $6.22^{\mathrm{a}} \pm 0.25$ & $6.27^{\mathrm{a}} \pm 0.24$ & 0.98 \\
\hline \multirow{2}{*}{$\mathrm{EC}(\mathrm{ds} / \mathrm{m})$} & 1 & $0.063^{\mathrm{a}} \pm 0.018$ & $0.053^{\mathrm{a}} \pm 0.013$ & $0.048^{\mathrm{a}} \pm 0.011$ & $0.051^{\mathrm{a}} \pm 0.013$ & 0.19 \\
\hline & 2 & $0.077^{\mathrm{a}} \pm 0.02$ & $0.053^{\mathrm{a}} \pm 0.02$ & $0.054^{\mathrm{a}} \pm 0.01$ & $0.069^{\mathrm{a}} \pm 0.02$ & 0.13 \\
\hline \multirow{2}{*}{$\mathrm{P}(\mathrm{ppm})$} & 1 & $23.81^{\mathrm{a}} \pm 2.92$ & $24.52^{\mathrm{a}} \pm 3.40$ & $24.16^{\mathrm{a}} \pm 2.56$ & $24.73^{\mathrm{a}} \pm 4.28$ & 0.66 \\
\hline & 2 & $26.18^{\mathrm{a}} \pm 4.72$ & $23.71^{\mathrm{a}} \pm 3.26$ & $24.84^{\mathrm{a}} \pm 4.39$ & $25.91^{\mathrm{a}} \pm 4.9$ & 0.75 \\
\hline \multirow{2}{*}{ OC (\%) } & 1 & $0.66^{\mathrm{a}} \pm 0.23$ & $0.59^{\mathrm{a}} \pm 0.15$ & $0.66^{\mathrm{a}} \pm 0.15$ & $0.63^{\mathrm{a}} \pm 0.17$ & 0.91 \\
\hline & 2 & $0.59^{\mathrm{a}} \pm 0.19$ & $0.65^{\mathrm{a}} \pm 0.12$ & $0.5^{\mathrm{a}} \pm 0.199$ & $0.66^{\mathrm{a}} \pm 0.21$ & 0.4 \\
\hline \multirow{2}{*}{ TN (\%) } & 1 & $0.15^{\mathrm{a}} \pm 0.04$ & $0.13^{\mathrm{a}} \pm 0.02$ & $0.11^{\mathrm{a}} \pm 0.06$ & $0.10^{\mathrm{a}} \pm 0.05$ & 0.26 \\
\hline & 2 & $0.18^{\mathrm{a}} \pm 0.09$ & $0.13^{\mathrm{ab}} \pm 0.04$ & $0.14^{\mathrm{ab}} \pm 0.029$ & $0.09^{\mathrm{b}} \pm 0.032$ & $0.03^{*}$ \\
\hline \multirow{2}{*}{ CEC (meq/100 g soil) } & 1 & $39.0^{\mathrm{a}} \pm 14.78$ & $49.0^{\mathrm{a}} \pm 4.17$ & $42.2^{\mathrm{a}} \pm 10.22$ & $45.27^{\mathrm{a}} \pm 3.98$ & 0.33 \\
\hline & 2 & $37.0^{\mathrm{a}} \pm 15.9$ & $47.3^{\mathrm{a}} \pm 6.92$ & $43.03^{\mathrm{a}} \pm 4.74$ & $48.27^{\mathrm{a}} \pm 3.88$ & 0.17 \\
\hline
\end{tabular}

Rows with the same superscript letters are not significantly different at $P<0.05$; soil depth with 1 and 2 represents $0-20 \mathrm{~cm}$ and $20-40 \mathrm{~cm}$, respectively.

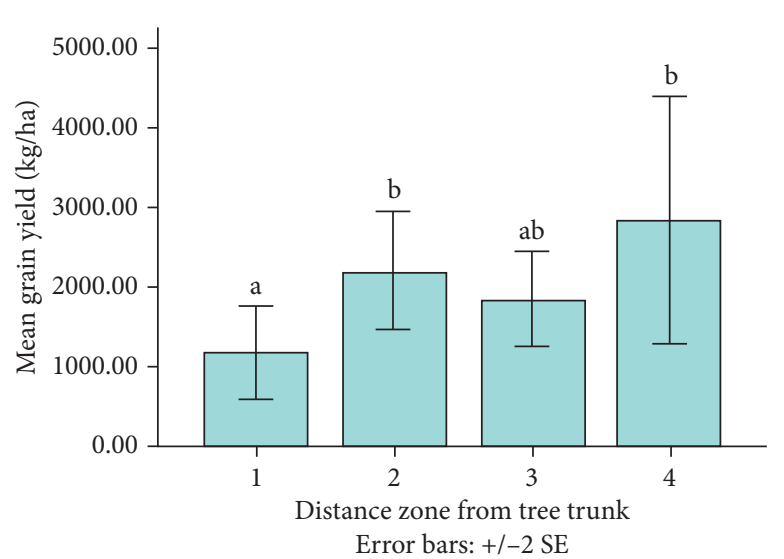

(a)

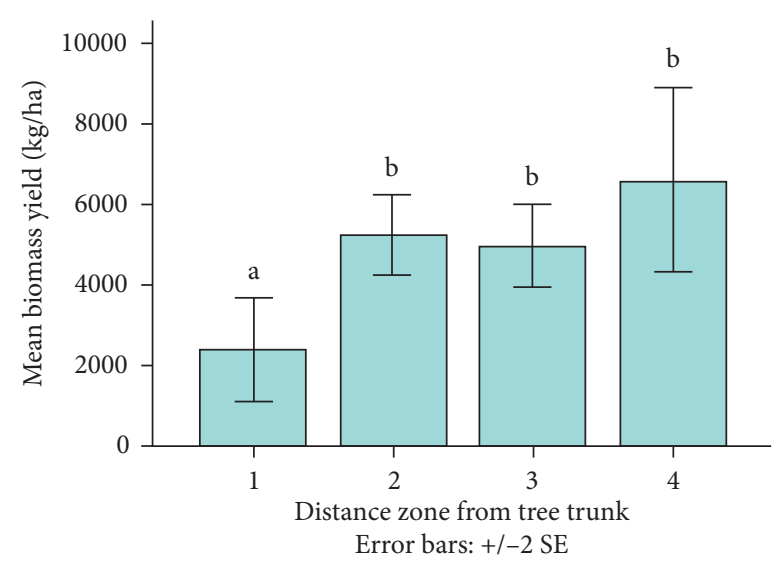

(b)

Figure 4: Effect of Acacia seyal on sorghum grain and biomass yield (kg/ha). Graphs with the same superscript letters are not statistically different at $P>0.05$.

contribute to the yield reduction effect [63]. The negative effect of Acacia seyal intercropping on sorghum yield and growth performance in South Sudan was also reported by Deng et al. [55]. However, other species such as Faidherbia albida were found to have a positive contribution to sorghum yield in the case of Tahtay Maychew district of northern Ethiopia [60].

\section{Conclusions}

The present findings showed that the widely grown Acacia seyal in the study area had small effect on selected soil physicochemical properties for both surface and subsurface soil layers. The positive effect was observed only on the subsurface total nitrogen availability. The species had negative effect on biomass and grain yield of sorghum due to the combined effect of the aboveground canopy and root competition of the species. Even though it was found less important in soil improvement and sorghum production enhancement, farmers allow growing the species on their farms and the reason might be the interest for its other production benefits such as fuelwood and cash value. Thus, it needs investigation on its off-farm socioeconomic benefits for understanding its alternative roles. The current research experiment work might not represent the whole Acacia seyal parkland system and was conducted on farmers' cropland which may not have similar management practices. Thus, for further research, it could be recommended to investigate wide area coverage, with controlled environment to bring a radical shift on the species intercropping system. Since the tree density and its management system also affect the productivity of companion crops on farmland, study for the determination of optimal tree density and its appropriate management for the species could be more beneficial.

\section{Data Availability}

Data used to support the findings of this study are available from the corresponding author upon request. 


\section{Conflicts of Interest}

The authors declare that they have no conflicts of interest.

\section{Acknowledgments}

First of all, the authors would like to thank the Almighty God for helping them to start and successfully complete this work. They are grateful to Guba Lafto district agricultural office staff members for their cooperation in site survey and field data collection. Ethiopian Environment and Forest Research Institute (EEFRI) is also acknowledged for funding their study and research work. Finally, their deepest gratitude goes to their beloved family for their inspiration, love, and support throughout their life.

\section{References}

[1] W. M. Mwangi, "Low use of fertilizers and low productivity in sub-Saharan Africa," Nutrient Cycling in Agro Ecosystems, vol. 47, no. 2, pp. 135-147, 1996.

[2] A. Syed and U. A. Jabeen, "Climate change impact on agriculture and food security," in Handbook of Research on Environmental Policies for Emergency Management and Public Safety, pp. 223-237, IGI Global, Hershey, PA, USA, 2018.

[3] EEA, Agriculture and Environment in EU-15-the IRENA Indicator Report, European Environment Agency, Copenhagen, Denmark, 2005.

[4] K. Biala, J. M. Terres, P. Pointereau, and M. L. Paracchini, "Low input farming systems: an opportunity to develop sustainable agriculture," in Proceedings of the JRC Summer University-Ranco, pp. 2-5, Sacramento, CA, USA, July 2007.

[5] "NZDL," The University of Walkato, 1991, http://www.nzdl. org.

[6] J. Pender, F. Place, and S. Ehui, Strategies for Sustainable Land Management in the East African Highlands, International Food Policy Research Institute, Washington, DC, USA, 2006.

[7] A. Waldron, D. Garrity, Y. Malhi, C. Girardin, D. C. Miller, and N. Seddon, "Agroforestry can enhance food security while meeting other Sustainable Development Goals," Tropical Conservation Science, vol. 10, 2017.

[8] L. A. Garibaldi, B. Gemmill-Herren, R. D’Annolfo, B. E. Graeub, S. A. Cunningham, and T. D. Breeze, "Farming approaches for greater biodiversity, livelihoods, and food security," Trends in Ecology \& Evolution, vol. 32, no. 1, pp. 68-80, 2017.

[9] M. Schaller, E. Barth, D. Blies, F. Röhrig, and M. Schümmelfeder, Climate Smart Agriculture (CSA): Climate Smart Agroforestry, CGIAR, Montpellier, France, 2017.

[10] L. Lipper, P. Thornton, B. M. Campbell et al., "Climate-smart agriculture for food security," Nature Climate Change, vol. 4, no. 12, pp. 1068-1072, 2014.

[11] M. K. M. Fahmi, D.-A. M. Dafa-Alla, M. Kanninen, and O. Luukkanen, "Impact of agroforestry parklands on crop yield and income generation: case study of rainfed farming in the semi-arid zone of Sudan," Agroforestry Systems, vol. 92, no. 3, pp. 785-800, 2018.

[12] R. P. Udawatta, C. J. Gantzer, and S. Jose, "Agroforestry practices and soil ecosystem services," in Soil Health And Intensification Of Agro Ecosytems, pp. 305-333, University of Missouri, Columbia, MO, USA, 2017.

[13] A. Belay, J. W. Recha, T. Woldeamanuel, and J. F. Morton, "Smallholder farmers' adaptation to climate change and determinants of their adaptation decisions in the Central Rift Valley of Ethiopia," Agriculture \& Food Security, vol. 6, no. 1, p. 24, 2017.

[14] M. A. Altieri and C. I. Nicholls, "The adaptation and mitigation potential of traditional agriculture in a changing climate," Climatic Change, vol. 140, no. 1, pp. 33-45, 2017.

[15] S. J. Vermeulen, P. K. Aggarwal, A. Ainslie et al., "Options for support to agriculture and food security under climate change," Environmental Science \& Policy, vol. 15, no. 1, pp. 136-144, 2012.

[16] Z. Jouzi, H. Azadi, F. Taheri et al., "Organic farming and small-scale farmers: main opportunities and challenges," Ecological Economics, vol. 132, pp. 144-154, 2017.

[17] G. Amanuel, R. F. Kühne, D. G. Tanner, and P. L. G. Vlek, "Biological nitrogen fixation in faba bean (Vicia faba L.) in the Ethiopian highlands as affected by $\mathrm{P}$ fertilization and inoculation," Biology and Fertility of Soils, vol. 32, no. 5, pp. 353-359, 2000.

[18] C. Orwa, A. Mutua, R. Kindt, R. Jamnadass, and A. Simons, Agroforestry Database: A Tree Species Reference and Selection Guide Version 4.0, World Agroforestry Centre ICRAF, Nairobi, Kenya, 2009.

[19] R. Lal and B. A. Stewart, Soil Management of Smallholder Agriculture, CRC Press, Boca Raton, FL, USA, 2014.

[20] A. K. Merine, E. Rodríguez-García, R. Alía, V. Pando, and F. Bravo, "Effects of water stress and substrate fertility on the early growth of Acacia Senegal and Acacia seyal from Ethiopian Savanna woodlands," Trees, vol. 29, no. 2, pp. 593-604, 2015.

[21] B. L. Dreyfus and Y. R. Dommergues, "Nodulation of Acacia species by fast- and slow-growing tropical strains of rhizobium," Applied and Environmental Microbiology, vol. 41, no. 1, pp. 97-99, 1981.

[22] Y. Y. Abdalla and I. M. Fangama, "Effect of shelterbelts on crop yield in Al-Rahad agricultural scheme, Sudan," International Journal of Current Microbiology and Applied Sciences, vol. 4, no. 7, pp. 1-4, 2015.

[23] Z. Woldu, M. Fetene, and A. Abate, "Vegetation under different tree species in Acacia woodland in the Rift Valley of Ethiopia," Sinet: Ethiopian Journal Of Science, vol. 22, no. 2, pp. 235-252, 1999.

[24] A. A. Mariod, N. M. F. Mohammed, F. O. Nabag, and A. A. Hassan, "Ethnobotanical study of three trees: indigenous knowledge on trees used as cosmetic in Khartoum State, Sudan," Asian Journal Of Pharmaceutical And Technology, vol. 4, pp. 178-182, 2014.

[25] D. Mengistie and D. Kidane, "Assessment of the impact of small-scale irrigation on household livelihood improvement at gubalafto district, North Wollo, Ethiopia," Agriculture, vol. 6, no. 3, p. 27, 2016.

[26] FAO, "The digital soil and terrain database of East Africa (SEA)," in Notes on the Arc Info Files Version 1.0, E. Lemma, Ed., Food And Agriculture Organization Of The United Nations, Rome, Italy, 1997.

[27] E. Lemma, Land use land cover dynamics in post-resettlement areas using cellular automata model: the case of Gubalafto Woreda, Ph.D. dissertation, Addis Ababa University, Addis Ababa, Ethiopia, 2012.

[28] L. P. Wilding, "Spatial variability: its documentation, accommodation and implication to soil surveys," in Soil Spatial Variability, pp. 166-194, SciEP, Las Vegas, NV, USA, 1985.

[29] T. K. Hartz, Soil Testing for Nutrient Availability: Procedures and Interpretation for California Vegetable Crop Production, Deptartment of Plant Sciences, Davis, CA, USA, 2007. 
[30] G. Estefan, R. Sommer, and J. Ryan, "Methods of soil, plant and water analysis," A Manual for the West Asia and North Africa Region, vol. 3, pp. 170-176, 2013.

[31] M. L. Jackson, Soil Chemical Analysis, vol. 498, pp. 183-204, Prentice Halls, Upper Saddle River, NJ, USA, 1958.

[32] S. R. Olsen, Estimation Of Available Phosphorus In Soils By Extraction With Sodium Bicarbonate, United States Department of Agriculture, Washington, DC, USA, 1954.

[33] H. D. Chapman, "Cation-exchange capacity," Methods of Soil Analysis. Part 2. Chemical and Microbiological Properties, vol. 9, pp. 891-901, 1965.

[34] A. Walkley and I. A. Black, "An examination of the Degtjareff method for determining soil organic matter, and a proposed modification of the chromic acid titration method," Soil Science, vol. 37, no. 1, pp. 29-38, 1934.

[35] N. C. Brady and R. R. Weil, The Nature and Properties of Soilsp. 960, 13th edition, Prentice-Hall, Upper Saddle River, NJ, USA, 2002.

[36] G. R. Blake and K. H. Hartge, "Bulk density," Methods Of Soil Analysis, Part 1, Physical And Mineralogical Methodspp. 363-367, Soil Science Society of America, Madison, WI, USA, 2nd edition, 1986.

[37] G. J. Bouyoucos, "Hydrometer method improved for making particle size analyses of soils 1," Agronomy Journal, vol. 54, no. 5, pp. 464-465, 1962.

[38] S. Yoshida, Fundamentals of Rice Crop Science, p. 269, The International Rice Research Institute, Los Baños, Philippines, 1981.

[39] J. H. Zar, Biostatistical Analysis, Pearson Education International, New York, NY, USA, 5th edition, 2009.

[40] J. Pallant, "SPSS survival manual," A Step by Step Guide to Data Analysis Using SPSS for Windows, 3rd edition, 2007.

[41] P. K. Gupta, Soil, Plant, Water and Fertilizer Analysis, Agrobios India, Jodhpur, India, 2006.

[42] R. Miller and R. Donahue, Soils in Our Environmentp. 649, 7th edition, Prentice-Hall, Upper Saddle River, NJ, USA, 1995.

[43] R. E. White, Principles and Practices of Soils Science: The Soil Is the Natural Resource, p. 348, Cambridge University Press, Cambridge, UK, 1997.

[44] A. A. Tanga, T. F. Erenso, and B. Lemma, "Effects of three tree species on microclimate and soil amelioration in the central rift valley of Ethiopia," Journal Of Soil Science And Environmental Management, vol. 5, no. 5, pp. 62-71, 2014.

[45] H. S. Wolle, B. Lemma, and T. Mengistu, "Effects of Ziziphus spina-christi (L.) on selected soil properties and sorghum yield in Habru District, North Wollo, Ethiopia," Malaysian Journal Of Medical And Biological Research, vol. 4, no. 2, pp. 61-68, 2017.

[46] E. W. Githae, C. K. Gachene, and J. T. Njoka, "Soil physicochemical properties under Acacia senegal varieties in the dryland areas of Kenya," African Journal Of Plant Science, vol. 5, no. 8, pp. 475-482, 2011.

[47] H. El Atta, I. Aref, and A. Ahmed, "Effect of Acacia spp. on soil properties in the highlands of Saudi Arabia," Life Science Journal, vol. 10, no. 4, pp. 100-105, 2013.

[48] J. J. Kessler and H. Breman, "The potential of agroforestry to increase primary production in the Sahelian and Sudanian zones of West Africa," Agroforestry Systems, vol. 13, no. 1, pp. 41-62, 1991.

[49] J. Seghieri, "The rooting patterns of woody and herbaceous plants in a savanna; are they complementary or in competition?" African Journal of Ecology, vol. 33, no. 4, pp. 358-365, 1995.
[50] H. Kassa, K. Gebrehiwet, and C. Yamoah, "Balanites aegyptiaca, a potential tree for parkland agroforestry systems with sorghum in Northern Ethiopia," Journal Of Soil Science And Environmental Management, vol. 1, no. 6, pp. 107-114, 2010.

[51] L. E. Akpo, V. A. Goudiaby, M. Grouzis, and H. N. Le Houerou, "Tree shade effects on soils and environmental factors in a Savanna of Senegal," West African Journal Of Applied Ecology, vol. 7, no. 1, pp. 41-52, 2005.

[52] Soil Survey Staff, "Soil survey field and laboratory methods manual," Soil Survey Investigations Report No. 51, Version 2.0. $R$, USDA's Natural Resources Conservation Service, Omaha, NE, USA, 2014.

[53] A. Manga, A. Diop, and T. A. Diop, "Functional diversity of mycorrhizal fungi has differential effects on salinity tolerance of Acacia seyal seedlings," Open Journal Of Soil Science, vol. 7, no. 11, pp. 315-332, 2017.

[54] F. Bernhard-Reversat and J. J. Loumeto, The Litter System in African Forest Tree PlantationsScience Publishers, Plymouth, UK, 2002.

[55] B. Deng, P. Tammeorg, O. Luukkanen, J. Helenius, and M. Starr, "Effects of Acacia seyal and biochar on soil properties and sorghum yield in agroforestry systems in South Sudan," Agroforestry Systems, vol. 91, no. 1, pp. 137-148, 2017.

[56] E. Wolde-meskel, Z. Terefework, K. Lindström, and A. Frostegård, "Rhizobia nodulating African Acacia spp. and Sesbania sesban trees in southern Ethiopian soils are metabolically and genomically diverse," Soil Biology And Biochemistry, vol. 36, no. 12, pp. 2013-2025, 2004.

[57] H. Sinare and L. J. Gordon, "Ecosystem services from woody vegetation on agricultural lands in Sudano-Sahelian West Africa," Agriculture, Ecosystems And Environment, vol. 200, pp. 186-199, 2015.

[58] G. Tilahun, "Soil fertility status as influenced by different land uses in Maybar areas of South Wello Zone, North Ethiopia," M.Sc. thesis, Haramaya University, Haramaya, Ethiopia, 2007.

[59] J. M. Boffa, S. B. Taonda, J. B. Dickey, and D. M. Knudson, "Field-scale influence of karité (Vitellaria paradoxa) on sorghum production in the Sudan zone of Burkina Faso," Agroforestry Systems, vol. 49, no. 2, pp. 153-175, 2000.

[60] M. Hassan, E. B. K. Hadgu, J. Mowo, C. Muthuri, A. Mwangi, and F. Sinclair, Agroforestry in Ethiopia: Using Trees on Farms to Boost Crop Productivity and Strengthen Food Security, Wolters Kluwer, Alphen aan den Rijn, Netherlands, 2016.

[61] F. A. Hassan, M. M. Hassan, and I. E. A. A. Babiker, "Allopathic effect of Acacia seyal (Talih) on germination and seedling growth of Sorghum bicolor (Sorghum)," Current Research International, vol. 11, no. 3, pp. 1-5, 2018.

[62] T. D. Wilson, R. M. Brook, and H. F. Tomlinson, "Interactions between nere (Parkia biglobosa) and under-planted sorghum in a parkland system in Burkina Faso," Experimental Agriculture, vol. 34, no. 1, pp. 85-99, 1998.

[63] M. Van Noordwijk, G. Lawson, K. Hairiah, and J. Wilson, "Root distribution of trees and crops: competition and/or complementarity," Tree-Crop Interactions: Agroforestry in a Changing Climate, pp. 221-257, CABI, Wallingford, UK, 2015. 